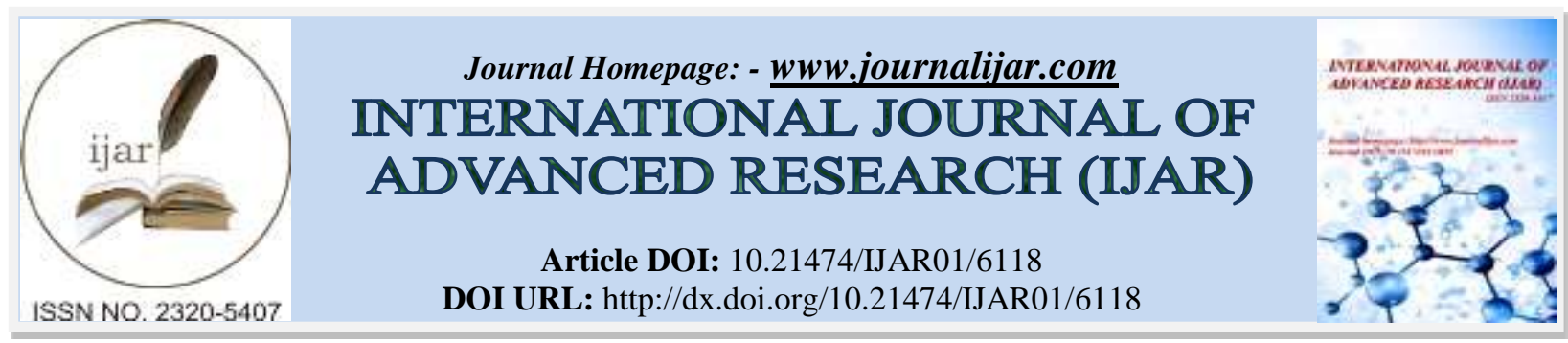

RESEARCH ARTICLE

\title{
LEADERSHIP STYLES IN PUBLIC AND PRIVATE SECTOR BANKS.
}

Mr. Rishabh Bapna.

Student, MBA (BFSI), School of BFSI, Symbiosis University of Applied Sciences, Indore.

\section{Manuscript Info}

Manuscript History

Received: 20 October 2017

Final Accepted: 22 November 2017

Published: December 2017

Keywords:-

Leadership styles, banking, relationship, perception, managers.

\begin{abstract}
In global scenario there are several changes and challenges faced by the Banking Industry especially by public and private sector banks where leadership plays an important role in achieving organizational goals. Leadership styles of Managers' in banks at various levels provide a sound background to the banking industry. Trait, behavioral and situational leadership studies, ability, dynamism, perceptions, attitudes of bank managers are helpful to manage problems in the banks and hence improvement in their performance. The study suggests that to an idea of leadership style that attempts to profile a person, you have to take in other factors, such as, how your peers and employees rate you as a leader, do you get your job done, do you take care of your employees, are you helping to "grow" your organization, etc. A survey was conducted to collect data using questionnaire. The data collected were analyzed using statistical tools. This paper examines the theory and conceptual understanding of the leadership styles in banking.
\end{abstract}

Copy Right, IJAR, 2017,. All rights reserved.

\section{Introduction:-}

The banking sector in India has been subjected to structural reforms since 1991 by easing the internal as well as external constraints in the working of the banks. The diversification of ownership of banking institutions has enabled private shareholding in public sector banks. The increasing presence of private sector domestic and foreign banks has led to an unprecedented increase in competition in the banking sector, offering tremendous opportunities of business expansion and diversification nationally as well as globally along with threats from the emergence of new players in the industry. Acute competition with the advent of new generation private sector banks and foreign banks bringing in latest technology has resulted in putting greater focus on product innovation backed by IT advancement and thrust on customization of products. High average age of staff in public sector banks has been toned down by offering voluntary retirement scheme. The banks are on hiring spree recruiting younger persons with good educational background and IT skills to manage their expansion plans. Effective leadership is viewed as a key factor in attracting, motivating, and maintaining employees in organizations undergoing change and transformation. (Sandhu and Kaur; Cropanzano, Rupp \& Byrme 2003). In today's competitive world, Banks play an important role in achieving the objective of economic development through financing every sector of the economy and help for the smooth operation.

\section{Review Of Literature:-}

The literature on leadership shows significant change from time to time. This Journal of Asian Business Strategy, literature starts from the theory of "Great Man" and comes to the most recent styles of transactional and 
transformational leadership and between of these two has been focusing on leader's traits, behaviors, and the situational/contingency factors.

The theory of "Great Man" is the starting point of the concept of leadership which states that leaders are always born and cannot be made. They have inborn qualities to become leaders that cannot be learnt. The word "Man" was used because initially men were only thought to be leaders (Bolden, 2004). Early research on leadership focused on leadership traits that state that if anybody has traits such as adaptive, ambitious, achievement-orientated, assertive, decisive, energetic, etc, then he is a leader or prospective leader (Stogdill, 1974; McCall, \& Lombardo, 1983; Boseman, 2008).

After that leadership theories focused on leaders' behaviors they showed in the past. Their behavioral patterns were studied so that other people could be provided training to act like leaders (Robbins \& Coulter, 2009). The next view about leadership came in the form of situational theory. According to this theory leader should analyze the situation and adopt his behavior according to the situational variables to improve leadership effectiveness. Important situational variables include characteristics of the followers, characteristics of the work environment and followers' tasks, and external environment. Situational theory was sometimes also called as contingency theory (Daft, 2005).

But modern literature on leadership generally takes into consideration two main styles of leadership that are transactional and transformational leadership. Transformational leadership Transformational leadership is what that motivates employees to achieve more rather than what was originally planned. It means to go beyond expectations (Krishnan, 2005). Transformational leadership has high impact on followers and changes their attitude and beliefs for their own interest and at the same time this change in behavior benefits the organization (Bums, 1978). Transformational leadership focuses on promoting development and strategic thinking in the organization and carries on the change process more effectively than others. Transformational leaders take care for others and never discriminate on the basis of race, color, sex, religion, age or social class (Chemjong, 2004).

The research on transformational leadership shows that high productivity, a decrease in the rate of job leaving and high level of job satisfaction are all due to this leadership style (Deluga, 1992; Marshall et al., 1992; Masi \& Cooke, 2000; Medley \& Larochelle, 1995; Sparks \& Schenk, 2001). Transactional leadership Transactional leadership is based on leader follower exchange where the follower acts according to the instructions of leader and leader rewards the followers. This satisfaction of needs improves employees' productivity and morale (Daft, 2005). Both transactional and transformational leadership showed different relationship with the job satisfaction in different scenarios. In some cases, transformational leadership proved itself as having significant relationship with job satisfaction and in other cases transactional leadership showed the same pattern. According to research studies conducted by (Wu, 2009) and (Epitropaki and Martin, 2005) that showed transactional leadership style provided high satisfaction as well as organizational identification compared to transformational leadership style.

\section{Rationale:-}

In today's competitive world, Banks play an important role in achieving the objective of economic development through financing every sector of the economy and help for the smooth operation. After studying problems faced by Banking Industry and Leadership styles. Researcher felt the need of study leadership, to guide banking staff for improvement of the performance of banks. The present purpose of the study is to check an idea of your leadership style in Public and Private Sector Banks.

\section{Research Questions:-}

1. What are different leadership styles?

2. What are different leadership styles adopted by managers in public and private sector bank?

3. How the personality traits of bank manager affect the leadership styles?

4. What are the factors affecting the leadership styles in public and private sector bank?

\section{Objective Of The Study:-}

After studying problems faced by Banking Industry and Leadership styles, Researcher felt the need of study leadership, to guide banking staff for improvement of the performance of banks. The study may achieve the following objectives:

1. To study different leadership styles in public and private sector bank.

2. To study different leadership styles adopted by managers in public and private sector bank. 
3. To study that personality traits of bank managers, affect the leadership styles followed.

4. To find out the various factors affecting the leadership styles in public and private sector bank.

\section{Research Methodology/Design:-}

The study is based on primary data collection through questionnaire and personal interviews of the bank managers under study. The study is concerned of leadership styles and role of bank managers at higher levels and their role in improving performance of banks in public and private sector bank. The study has taken, following assumptions, which have been tested using various tests in the study.

\section{Scoring Section :-}

After completing Questionnaire, transfer your answers to the spaces below:

People

Question

1.

4.

6.

9.

10 .

12.

14.

16.

17.

TOTAL

$\mathrm{X} 0.2=$

(Multiply the Total by 0.2 to get your final score)
Task

Question

2 .

3.

5.

7.

8.

11.

13.

15 .

18.

TOTAL

X 0.2

(Multiply the Total by 0.2 to get your final score)

\section{Sample Size/Sampling Frame:-}

Primary research is based on (survey sampling) survey may refer to many types of techniques or observation. This survey was done based on 30 middle and senior level managers of commercial banks, near Indore through mail Opinions and by personal interview. It includes- S.B.I., Bank of India, Bank of Baroda, P.N.B., Icici Bank, Axis Bank, Hdfc Bank, UCO bank etc. The study is based on Independent variables like- situational variable, personally centred variable etc.

Dependent variables have been selected as- leadership styles.

\section{Tools Of Data Collection:-}

The basic design of survey instruments consists of structured questionnaires. It is designed to collect all the required from managers. Based on their perception, knowledge and information source related to the fourteen principles of management and their relevance in 2017.

Scale:-

The scale used in the questionnaire is Likert Scale (Interval scale) and Nominal Scale.

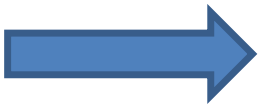

\section{Never Sometimes Always

$\begin{array}{llllll}0 & 1 & 2 & 3 & 4 & 5\end{array}$

\section{Data source:-}

The sources of data are primary. Primary data is collected through questionnaires from the managers of Banking organizations.

\section{Tools of Data Analysis:-}

The data and information collected will be classified, tabulated and processed and its findings presented in a systematic manner by using pie charts, tables and graphs. 


\section{Classification Of Respondents:-}

SEX

\section{0 responses}

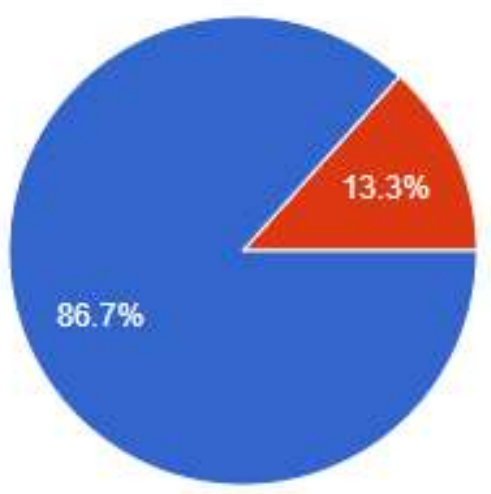

\section{NAME OF ORGANISATION(BANK NAME)}

\section{0 responses}

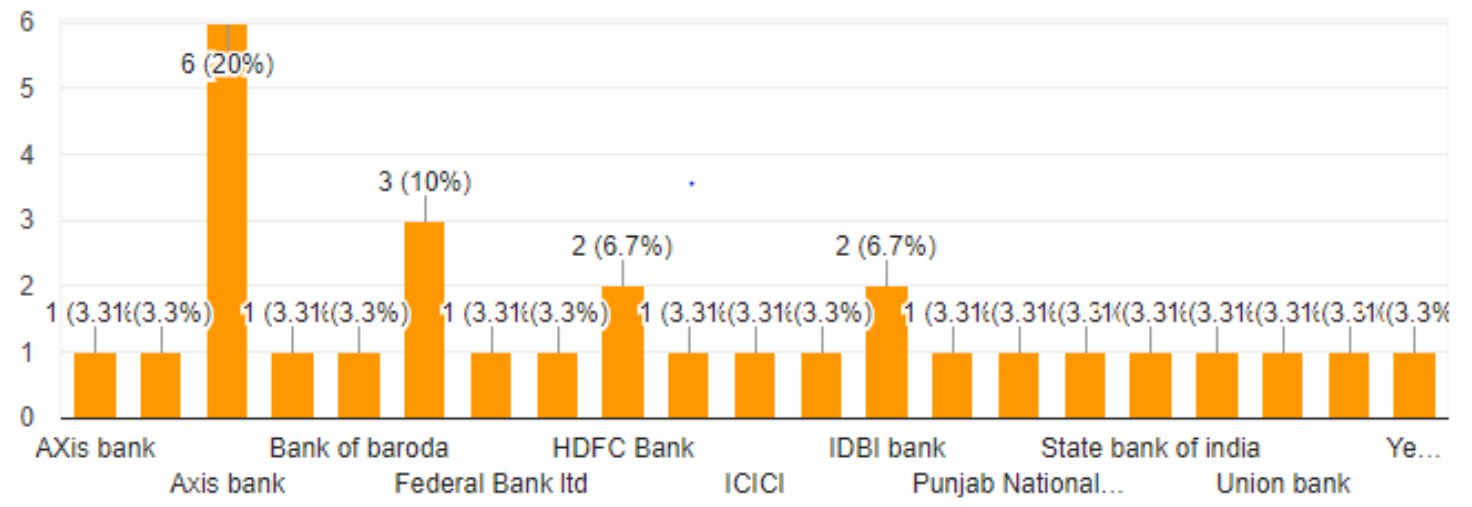

\section{AGE}

\section{0 responses}

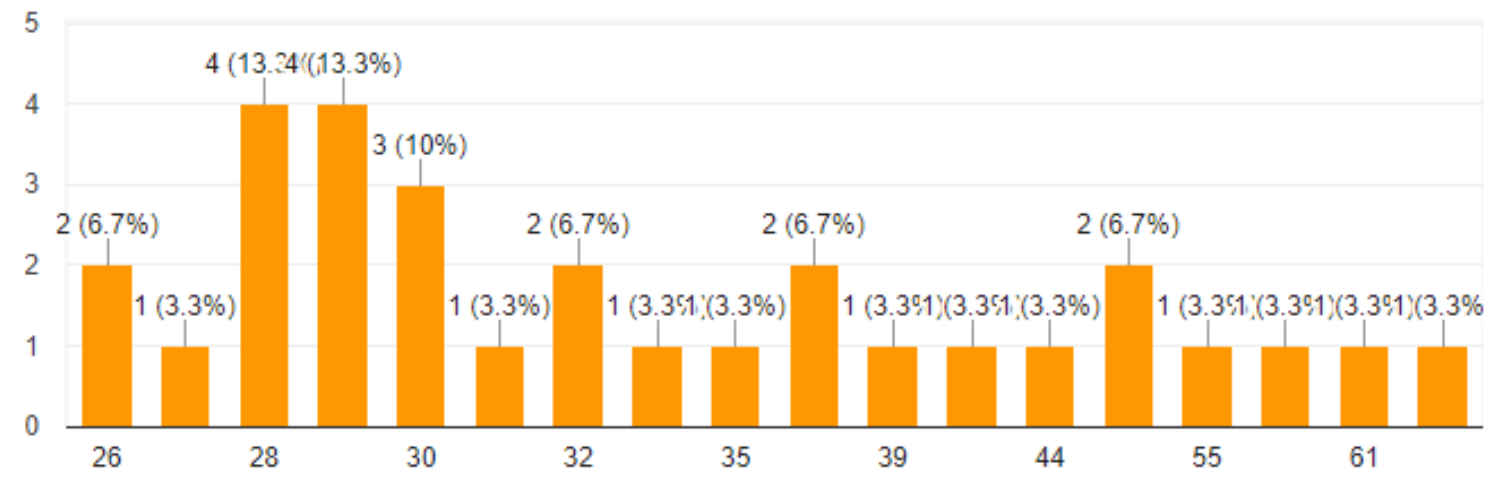




\section{QUESTIONS}

Q1. I encourage my team to participate when it Comes decision-making time and I try to implement their ideas and suggestions.

\section{0 responses}

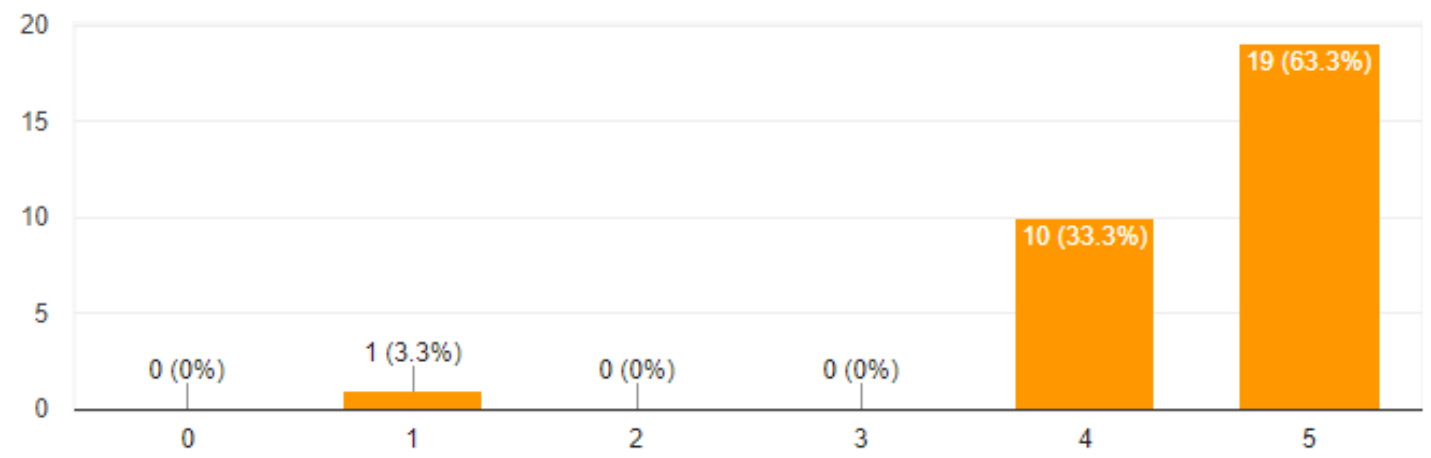

Majority of Leaders always encourage their team players to participate in decision making.

Q2. Nothing is more important than accomplishing a goal or task.

\section{0 responses}

20

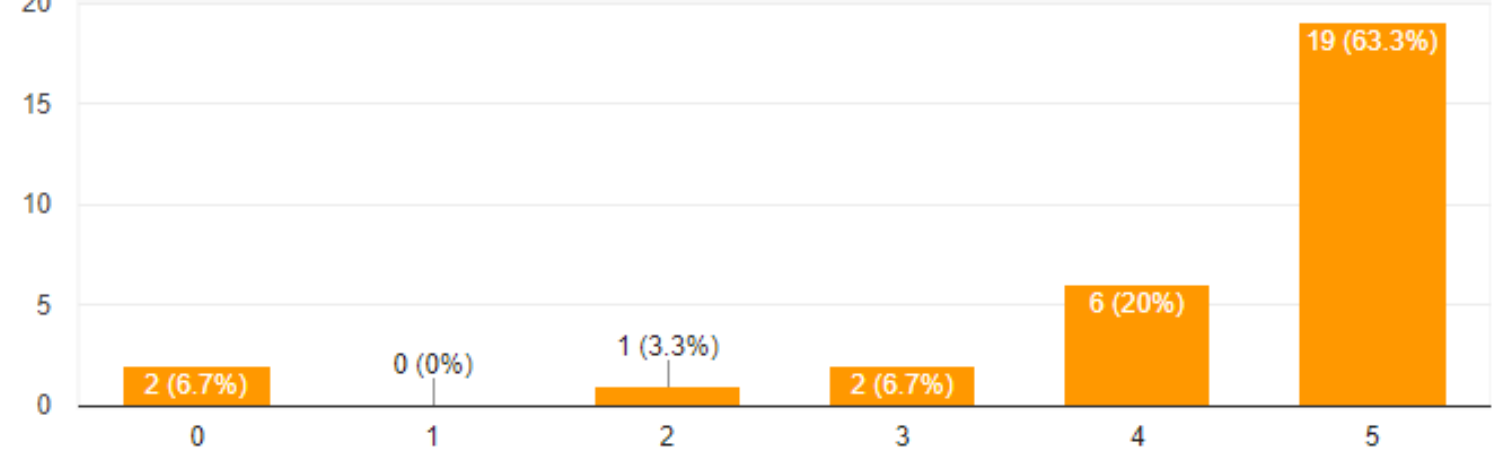

Majority of Leaders always think accomplishing a goal or task is important. 
Q3. I closely monitor the schedule to ensure a task or project will be completed in time.

\section{0 responses}

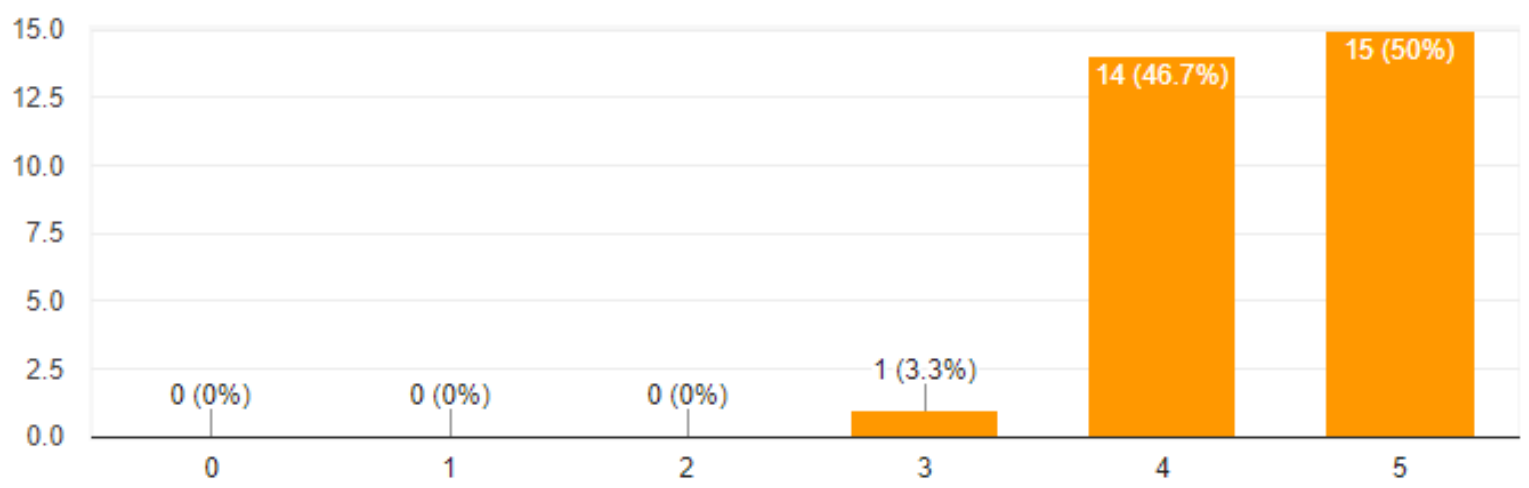

Majority of Leaders closely monitor the schedule to ensure a task or project will be completed in time.

Q4. I enjoy coaching people on new tasks and procedures.

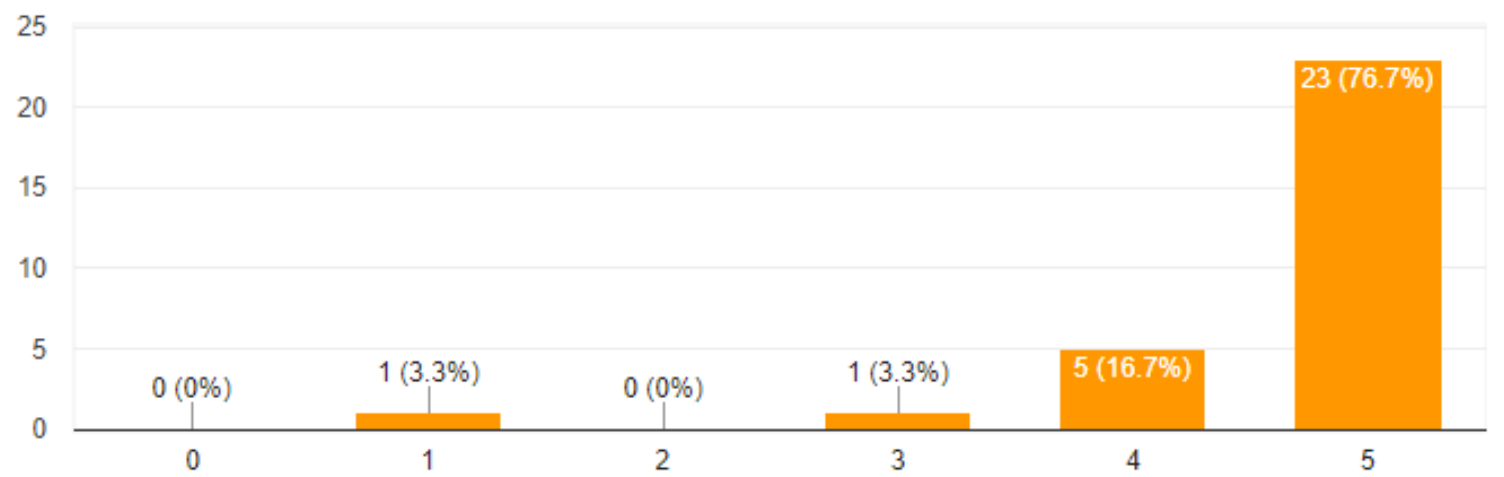

Majority of Leaders always enjoy coaching people on new tasks and procedures. 
Q5. The more challenging a task is, the more I enjoy it.

\section{0 responses}

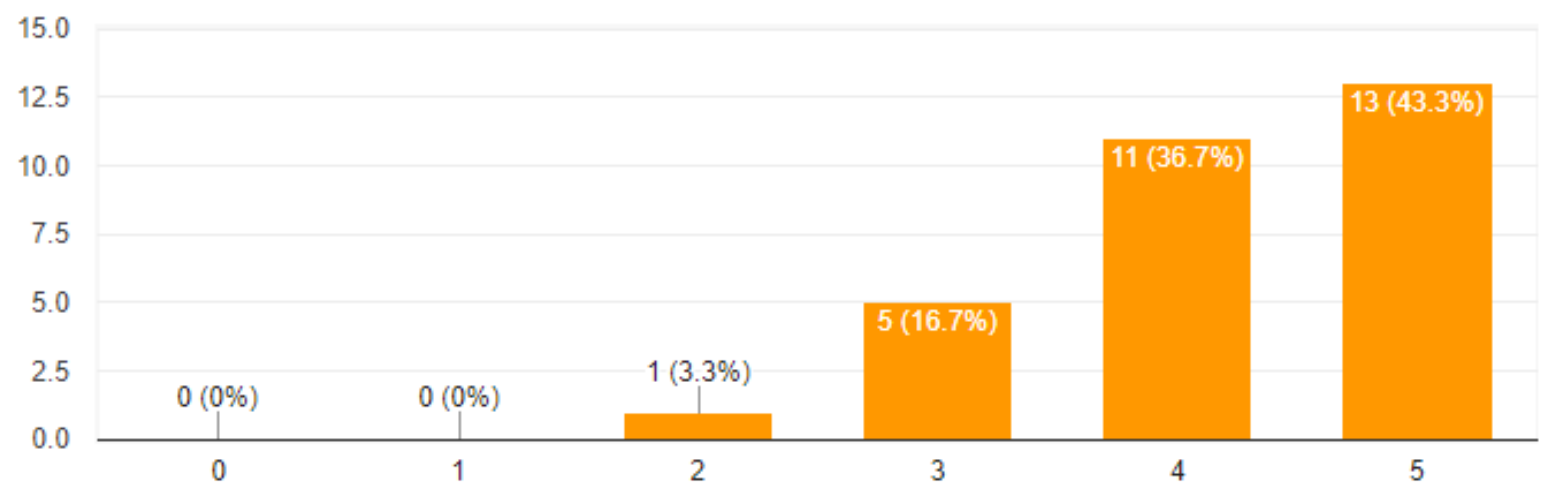

Majority of Leaders think that the more challenging a task is, the more they enjoy it.

Q6. I encourage my employees to be creative about their job.

\section{0 responses}

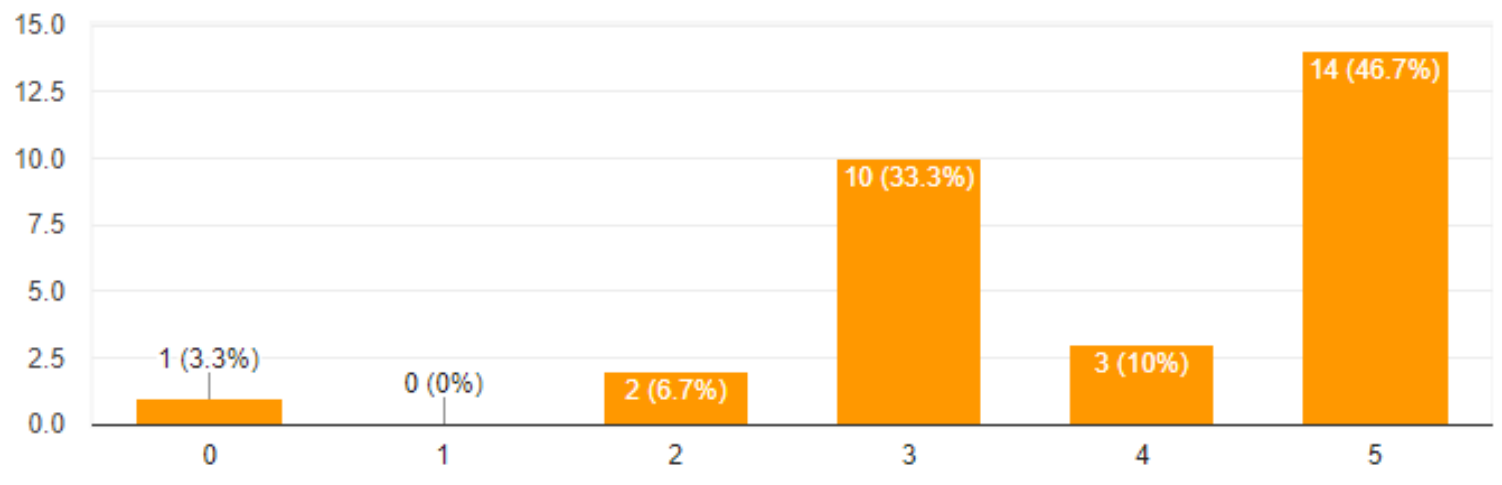

Majority of Leaders always encourage the employee to be creative about their job. 
Q7. When seeing a complex task through to completion, I ensure that every detail is accounted for.

30 responses

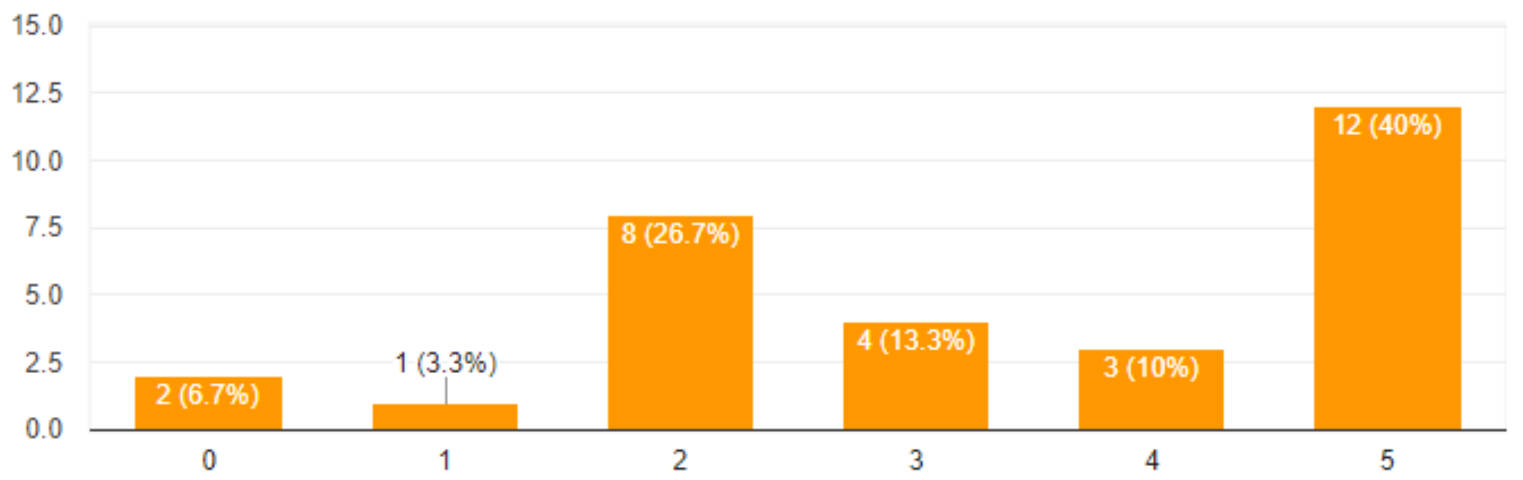

Majority of Leaders always see a complex task through to completion and ensure that every detail is accounted.

Q8.I find it easy to carry out several complicated tasks at the same time.

\section{0 responses}

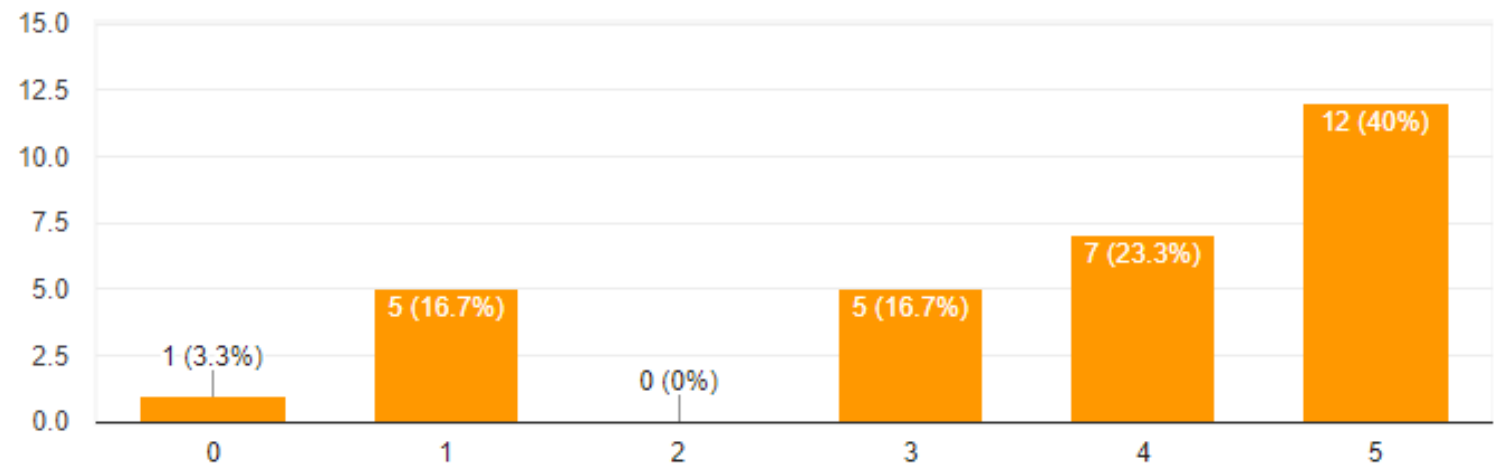

Majority of Leaders always find it easy to carry out several complicated tasks at the same time. 
Q9. I enjoy reading articles, books, and journals about training, leadership, and psychology; and then putting what I have read into action.

\section{0 responses}

20

15

10

$51(3.3 \%)$

0

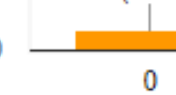

\section{$6(20 \%)$} $2(6.7 \%)$

1

\section{$3(10 \%)$}

3

\section{$2(6.7 \%)$}

4

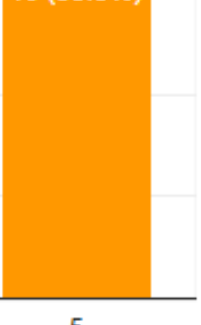

Majority of Leaders always enjoy reading articles, books, and journals about training, leadership, and psychology and then putting what they have read into action.

Q10. When correcting mistakes, I do not worry about jeopardizing relationships.

\section{0 responses}

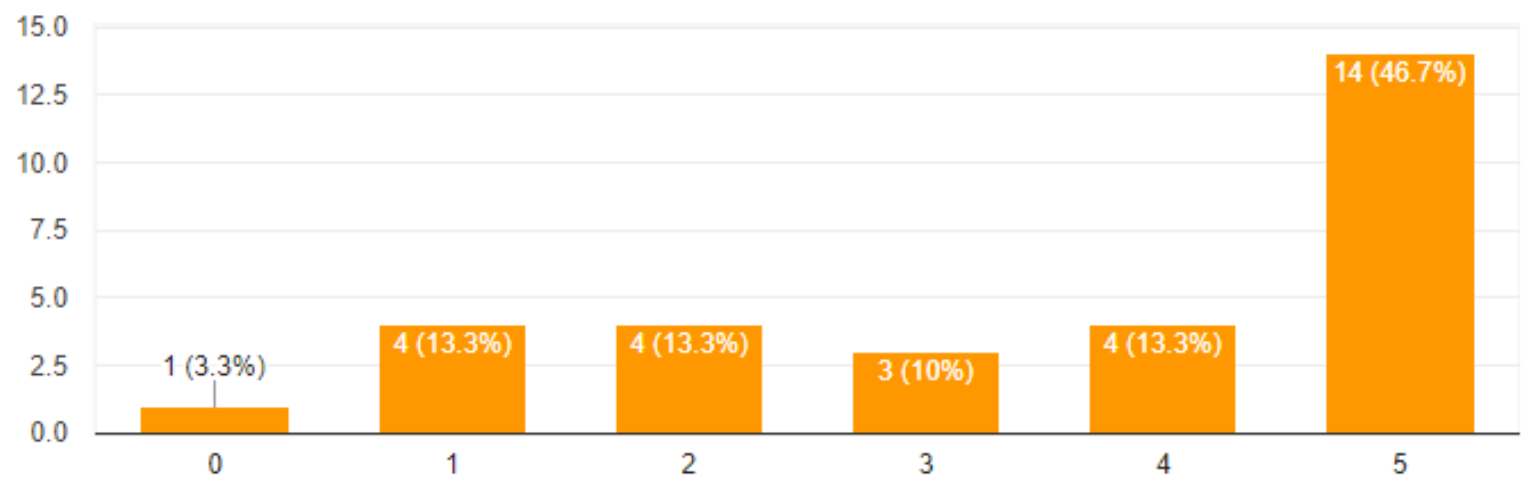

Majority of Leaders always while correcting mistakes, they do not worry about jeopardizing relationships. 
Q11. I manage my time very efficiently.

30 responses

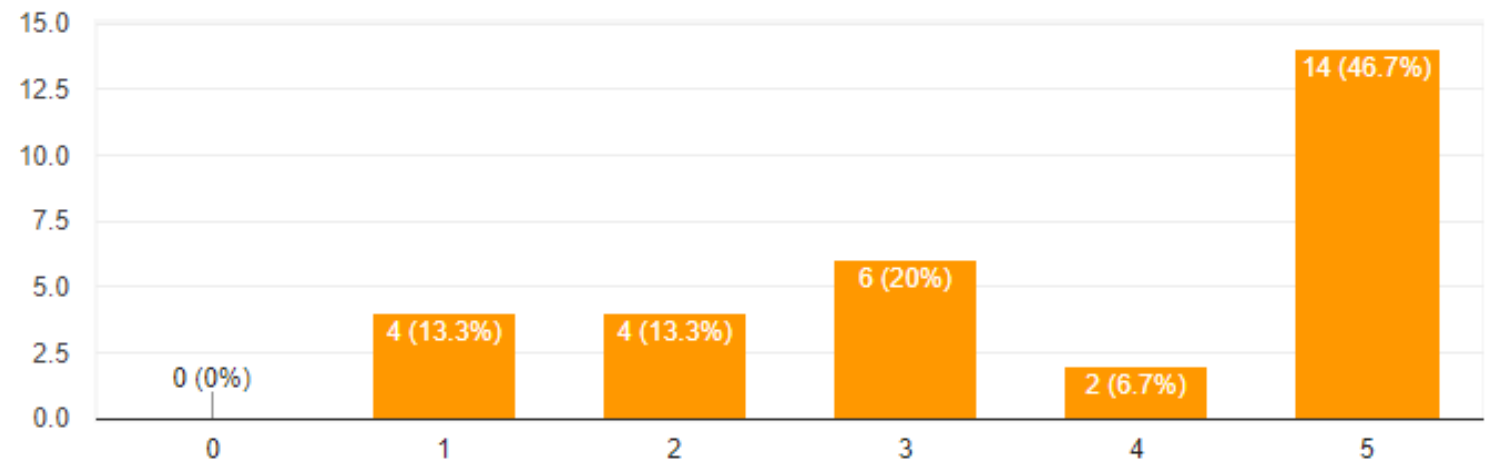

Majority of Leaders always manage their time very efficiently.

Q12. I enjoy explaining the intricacies and details of a complex task or project to my employees.

30 responses

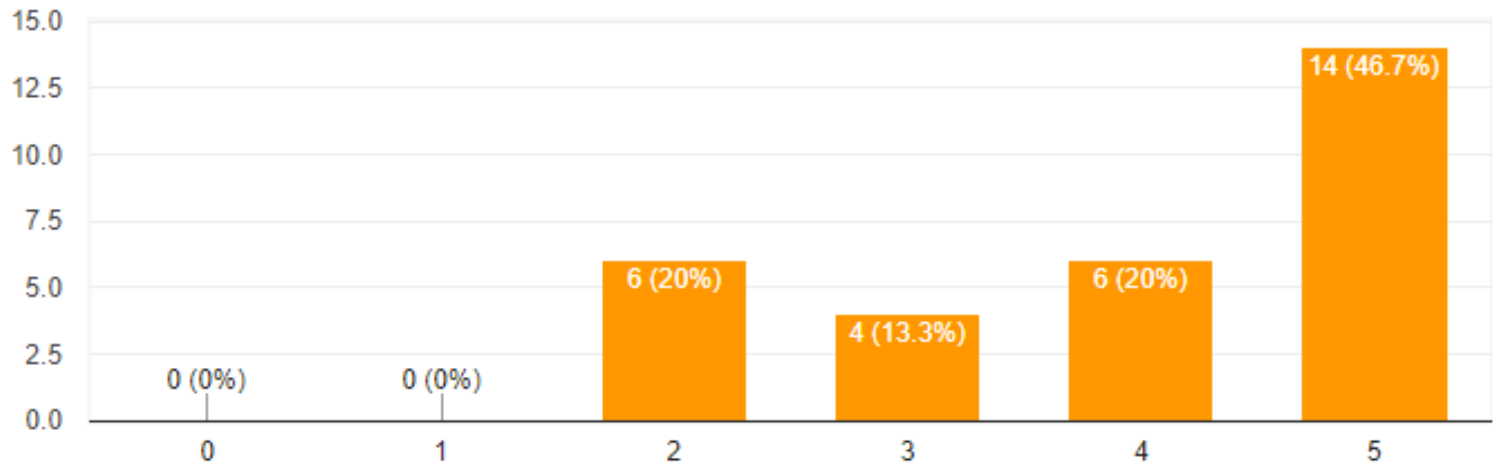

Majority of Leaders always enjoy explaining the intricacies and details of a complex task or project to the employees. 
Q13. Breaking large projects into small manageable tasks is second nature to me.

30 responses

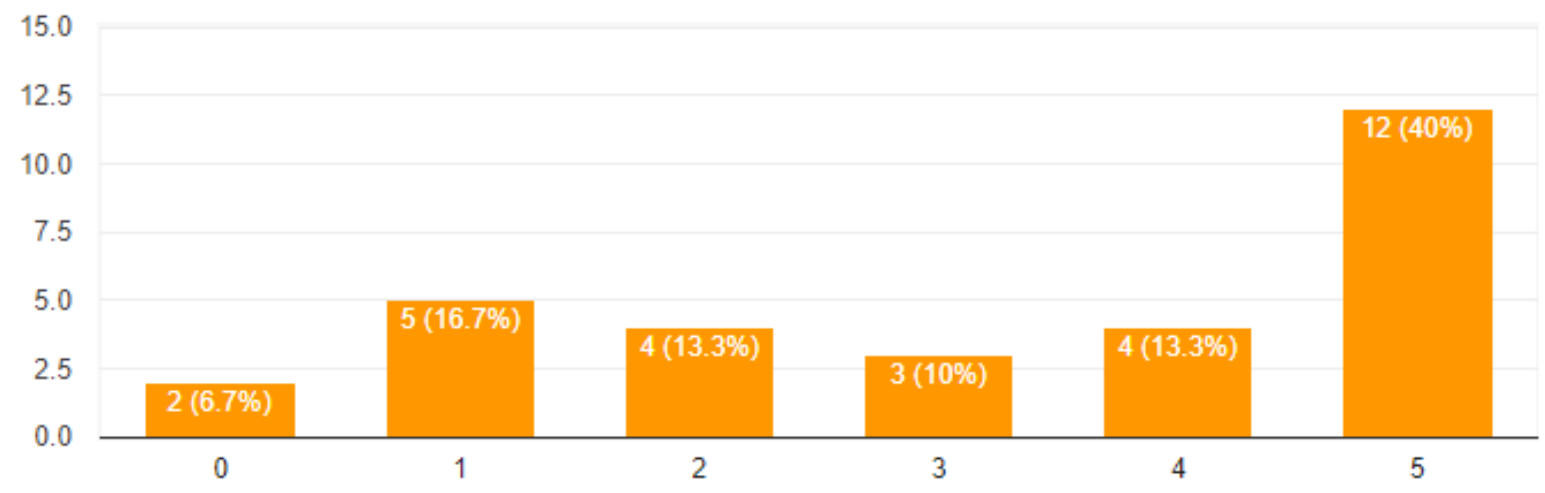

Majority of Leaders always break large projects into small manageable tasks.

Q14. Nothing is more important than building a great team.

\section{0 responses}

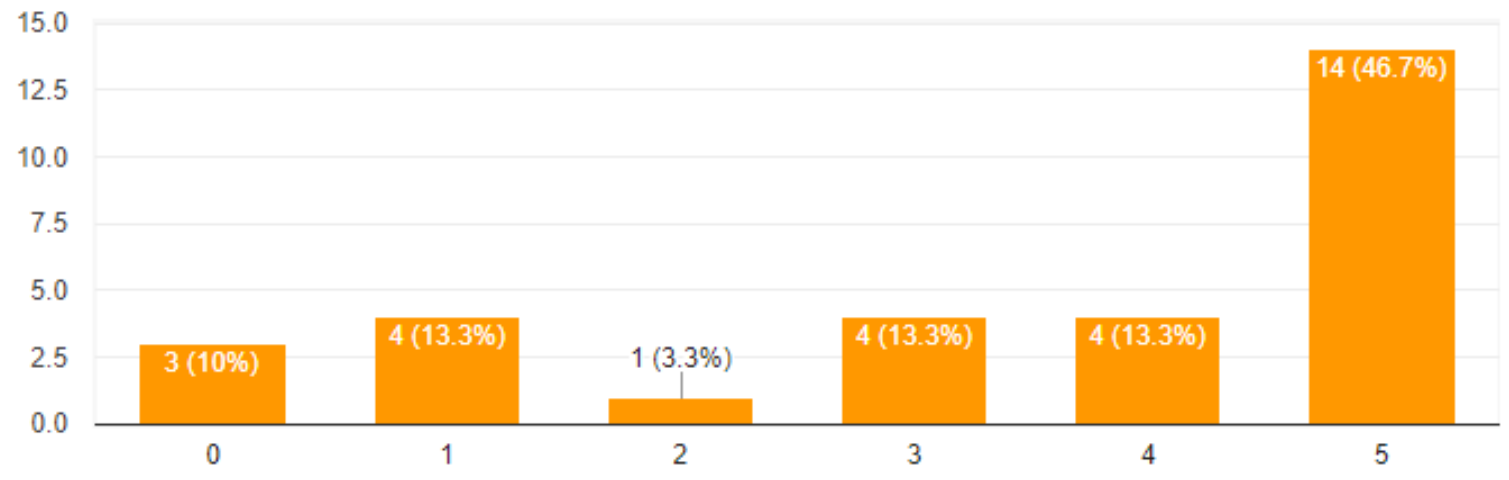

Majority of Leaders always think nothing is more important than building a great team. 
Q15. I enjoy analyzing problems.

30 responses

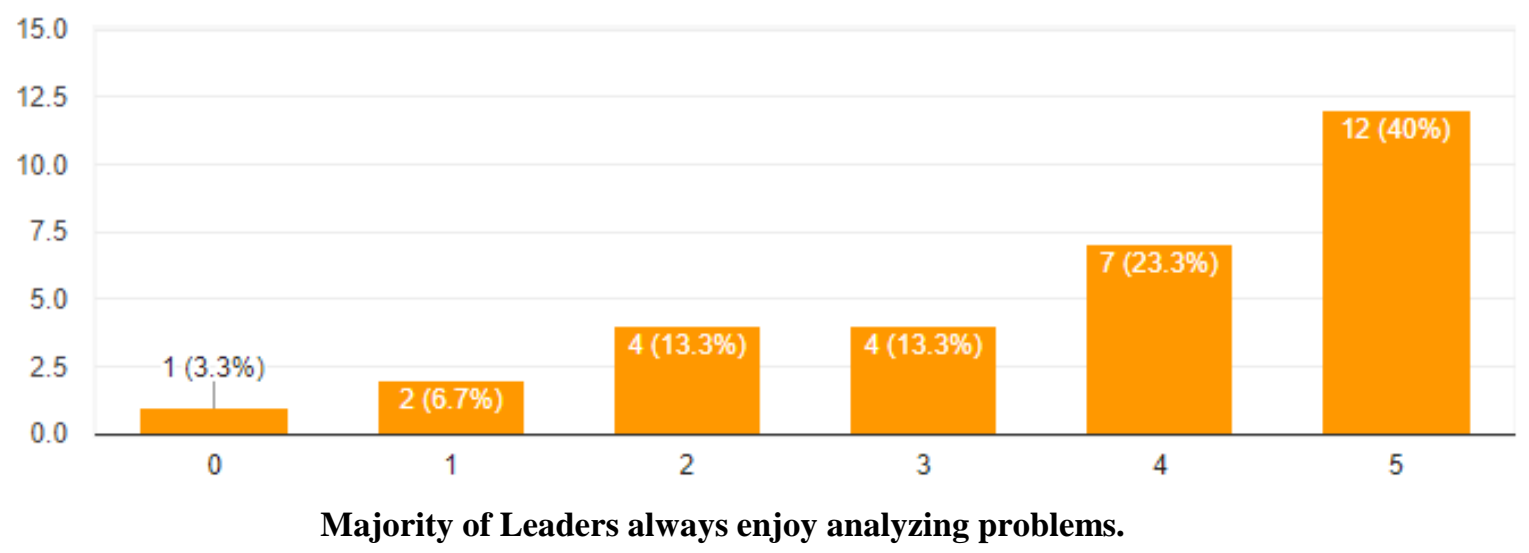

Q16. I honor other people's boundaries.

30 responses

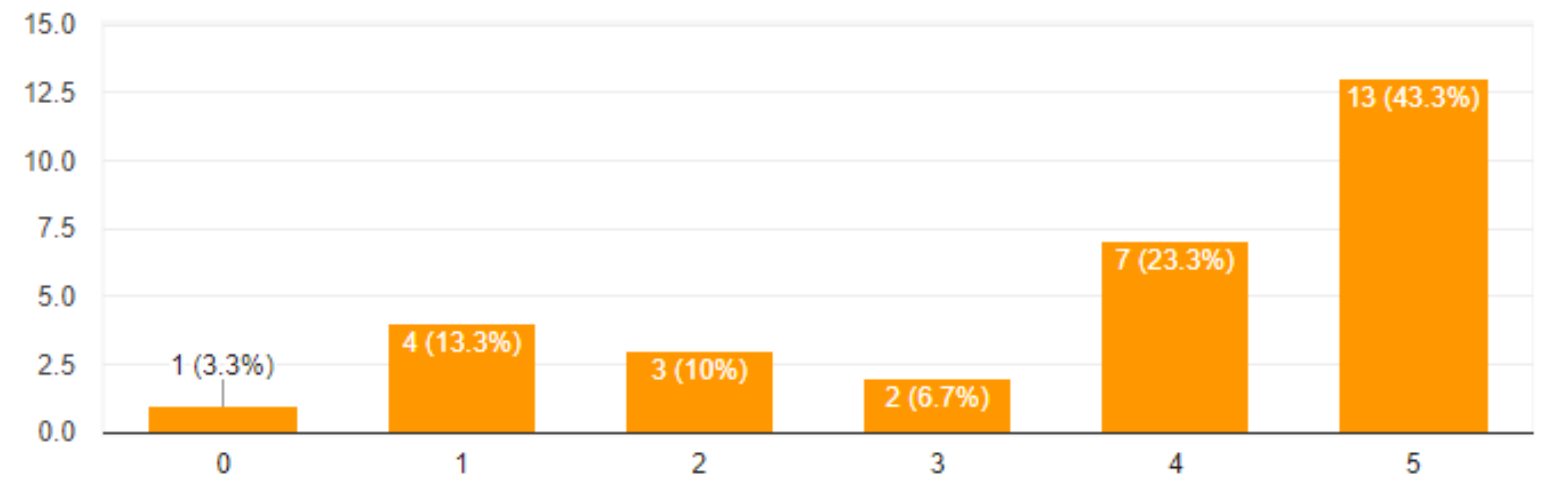

Majority of Leaders always honor other people's boundaries. 
Q17. Counseling my employees to improve their performance or behavior is second nature to me.

\section{0 responses}

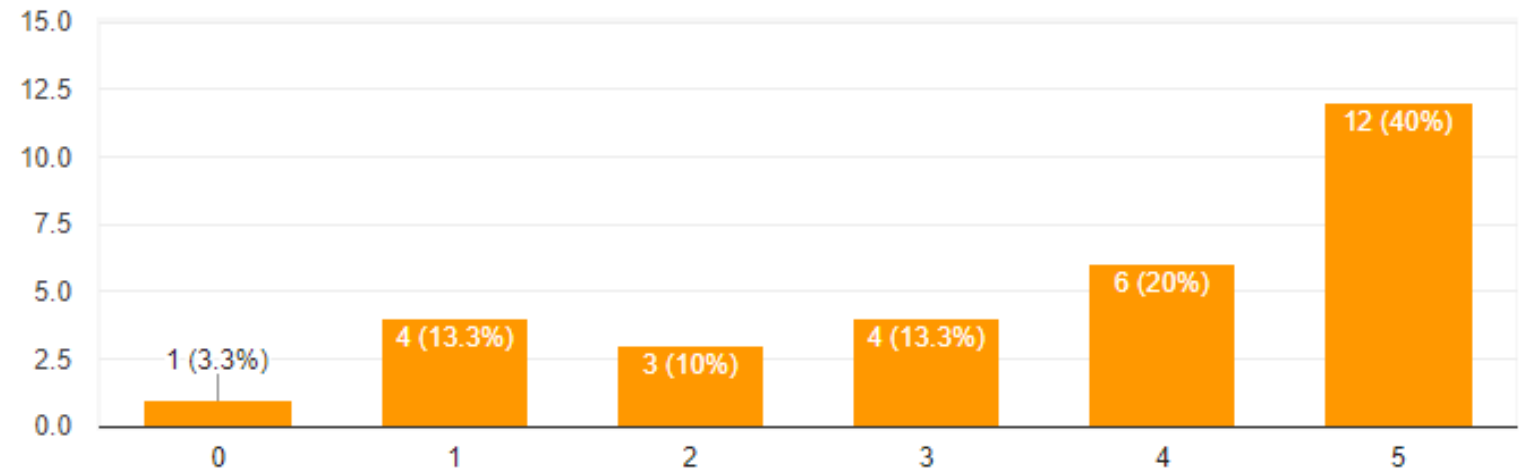

Majority of Leader do counseling of the employees to improve their performance or behavior.

Q18. I enjoy reading articles, books, and trade journals about my profession; and then implementing the new procedures I have learned.

30 responses

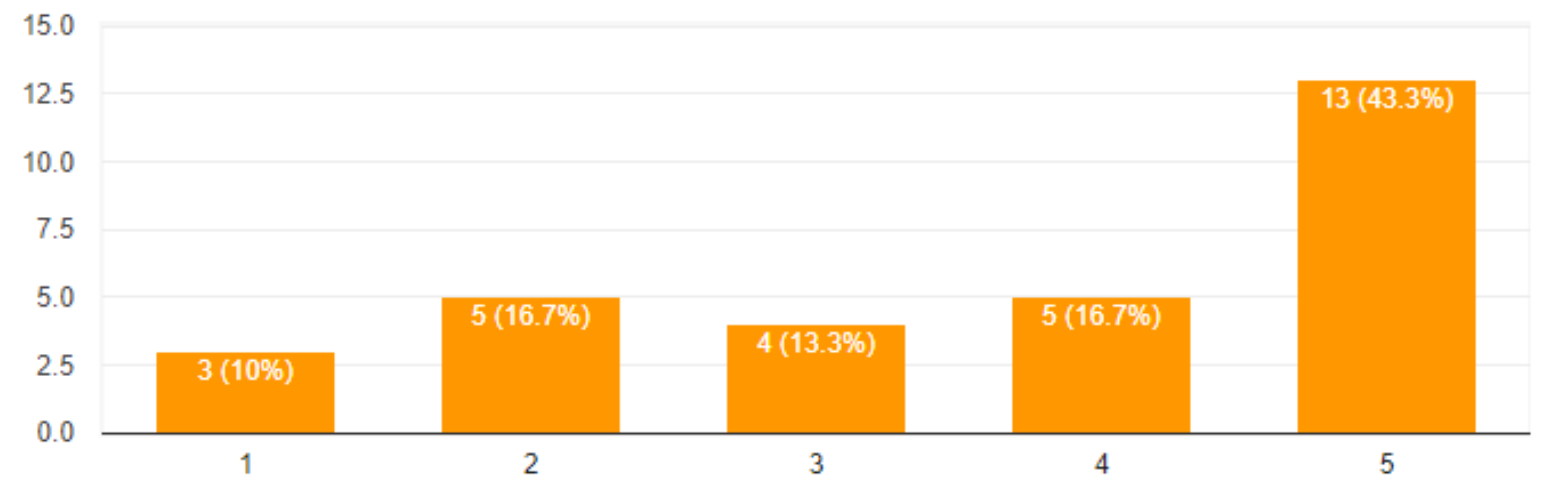

Majority of Leaders always enjoy reading articles, books, and trade journals about their profession; and then implementing the new procedures they have learned. 


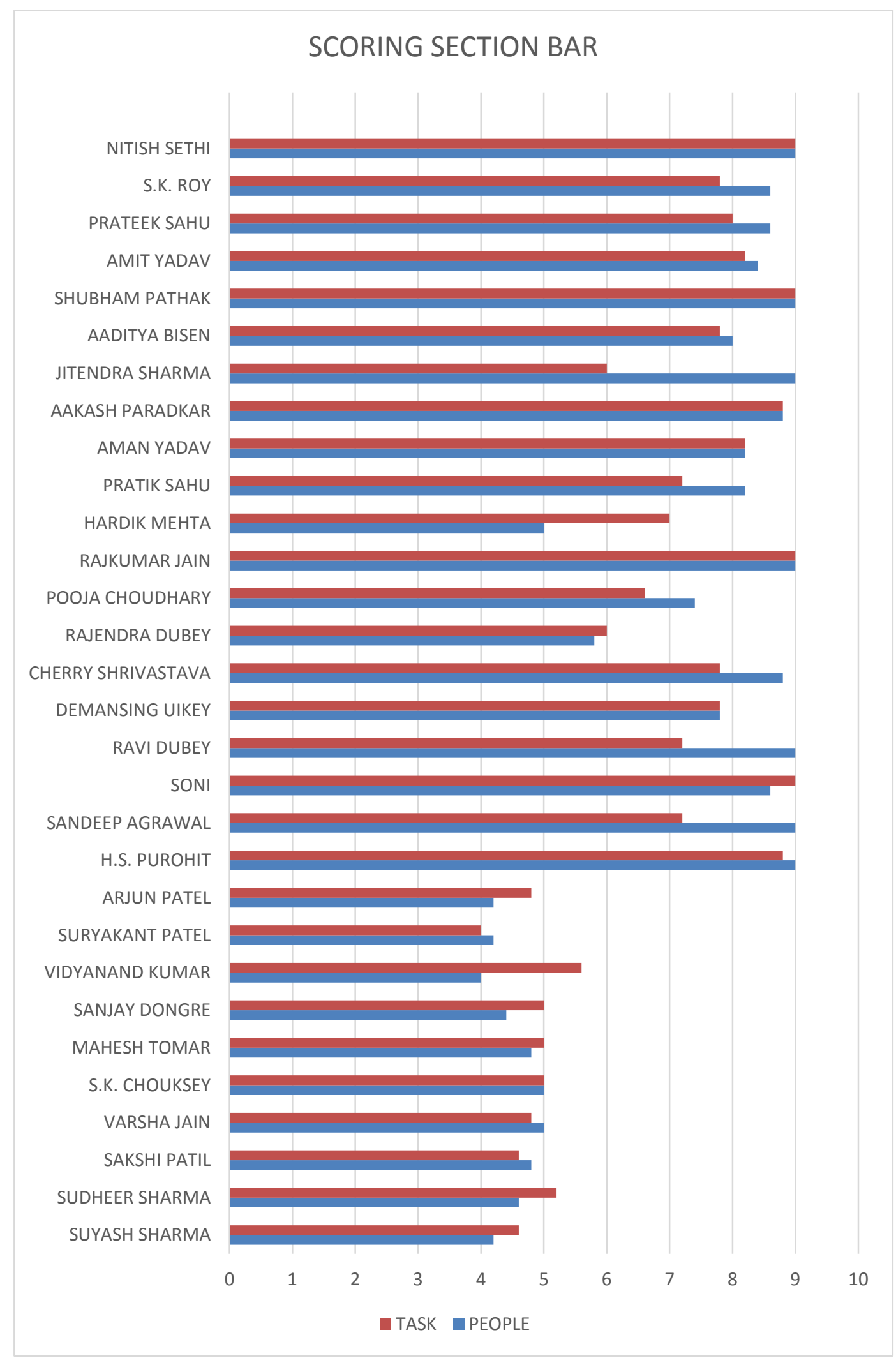




\begin{tabular}{|c|c|c|c|c|}
\hline S.No & Name & People & Task & Leadership style \\
\hline 1. & SUYASH SHARMA & 4.2 & 4.6 & Impoverished Leader \\
\hline 2. & SUDHEER SHARMA & 4.6 & 5.2 & Authoritarian Leader \\
\hline 3. & SAKSHI PATIL & 4.8 & 4.6 & Impoverished Leader \\
\hline 4. & VARSHA JAIN & 5 & 4.8 & Impoverished Leader \\
\hline 5. & S.K. CHOUKSEY & 5 & 5 & Impoverished Leader \\
\hline 6. & MAHESH TOMAR & 4.8 & 5 & Impoverished Leader \\
\hline 7. & SANJAY DONGRE & 4.4 & 5 & Impoverished Leader \\
\hline 8. & VIDYANAND KUMAR & 4 & 5.6 & Country Club Leader \\
\hline 9. & SURYAKANT PATEL & 4.2 & 4 & Impoverished Leader \\
\hline 10. & ARJUN PATEL & 4.2 & 4.8 & Impoverished Leader \\
\hline 11. & H.S. PUROHIT & 9 & 8.8 & Team Leader \\
\hline 12. & SANDEEP AGRAWAL & 9 & 7.2 & Team Leader \\
\hline 13. & SONI & 8.6 & 9 & Team Leader \\
\hline 14. & RAVI DUBEY & 9 & 7.2 & Team Leader \\
\hline 15. & DEMANSING UIKEY & 7.8 & 7.8 & Team Leader \\
\hline 16. & CHERRY SHRIVASTAVA & 8.8 & 7.8 & Team Leader \\
\hline 17. & RAJENDRA DUBEY & 5.8 & 6 & Team Leader \\
\hline 18. & POOJA CHOUDHARY & 7.4 & 6.6 & Team Leader \\
\hline 19. & RAJKUMAR JAIN & 9 & 9 & Team Leader \\
\hline 20. & HARDIK MEHTA & 5 & 7 & Authoritarian Leader \\
\hline 21. & PRATIK SAHU & 8.2 & 7.2 & Team Leader \\
\hline 22. & AMAN YADAV & 8.2 & 8.2 & Team Leader \\
\hline 23. & AAKASH PARADKAR & 8.8 & 8.8 & Team Leader \\
\hline 24. & JITENDRA SHARMA & 9 & 6 & Team Leader \\
\hline 25. & AADITYA BISEN & 8 & 7.8 & Team Leader \\
\hline 26. & SHUBHAM PATHAK & 9 & 9 & Team Leader \\
\hline 27. & AMIT YADAV & 8.4 & 8.2 & Team Leader \\
\hline 28. & PRATEEK SAHU & 8.6 & 8 & Team Leader \\
\hline 29. & S.K. ROY & 8.6 & 7.8 & Team Leader \\
\hline 30. & NITISH SETHI & 9 & 9 & Team Leader \\
\hline
\end{tabular}

Authoritarian Leader:-

(high task, low relationship) People who get this rating are very much task oriented and are hard on their workers (autocratic). There is little or no allowance for cooperation or collaboration. Heavily task oriented people display these characteristics: they are very strong on schedules; they expect people to do what they are told without question or debate; when something goes wrong they tend to focus on who is to blame rather than concentrate on exactly what is wrong and how to prevent it; they are intolerant of what they see as dissent (it may just be someone's creativity), so it is difficult for their subordinates to contribute or develop.

\section{Team Leader:-}

(high task, high relationship) This type of person leads by positive example and endeavours to foster a team environment in which all team members can reach their highest potential, both as team members and as people. They encourage the team to reach team goals as effectively as possible, while also working tirelessly to strengthen the bonds among the various members. They normally form and lead some of the most productive teams.

\section{Country Club Leader:-}

(low task, high relationship) This person uses predominantly reward power to maintain discipline and to encourage the team to accomplish its goals. Conversely, they are almost incapable of employing the more punitive coercive and legitimate powers. This inability results from fear that using such powers could jeopardize relationships with the other team members. 


\section{Impoverished Leader:-}

(low task, low relationship) A leader who uses a "delegate and disappear" management style. Since they are not committed to either task accomplishment or maintenance; they essentially allow their team to do whatever it wishes and prefer to detach themselves from the team process by allowing the team to suffer from a series of power struggles.

The most desirable place for a leader to be along the two axis at most times would be a 9 on task and a 9 on people - the Team Leader. However, do not entirely dismiss the other three. Certain situations might call for one of the other three to be used at times. For example, by playing the Impoverished Leader, you allow your team to gain selfreliance. Be an Authoritarian Leader to instill a sense of discipline in an unmotivated worker. By carefully studying the situation and the forces affecting it, you will know at what points along the axis you need to be in order to achieve the desired result.

\section{The Results:-}

This chart will give you an idea of your leadership style. But, like any other instrument that attempts to profile a person, you have to take in other factors, such as, how your peers and employees rate you as a leader, do you get your job done, do you take care of your employees, are you helping to "grow" your organization, etc.

You should review the statements in the survey and reflect on the low scores by asking yourself, "If I scored higher in that area, would I be a more effective leader?" And if the answer is yes, then it should become a personal action item. The research study conducted shows that Team Leader is more effective leadership styles which is preferred by people in banking style. From the above observation I founded that there is a high task and high relationship among bank leaders in Public and Private sector banks.

\section{References:-}

1. Dr Sandhya Mehta (2016), “A Review Paper on leadership styles of managers among public and private sector banks and its relationship with other constructs". International Journal of New Innovations in Engineering and Technology-Volume 4 Issue 4.

2. Ajay Jain (2014), "Leadership Styles of Bank Managers in Nationalized Commercial Banks of India". Purushartha: A Journal of Management Ethics and Spirituality-Vol. VII, No. 1. 